\title{
Miranda
}

Revue pluridisciplinaire du monde anglophone /

Multidisciplinary peer-reviewed journal on the English-

speaking world

$12 \mid 2016$

Mapping gender. Old images ; new figures

\section{Susan Glaspell Revisited: Century Old Play Returns to its Roots}

Performance Review

Denise Doherty Pappas

\section{OpenEdition}

Electronic version

URL: http://journals.openedition.org/miranda/8220

DOI: $10.4000 /$ miranda. 8220

ISSN: 2108-6559

\section{Publisher}

Université Toulouse - Jean Jaurès

\section{Electronic reference}

Denise Doherty Pappas, "Susan Glaspell Revisited: Century Old Play Returns to its Roots", Miranda [Online], 12 | 2016, Online since 29 February 2016, connection on 16 February 2021. URL: http:// journals.openedition.org/miranda/8220 ; DOl: https://doi.org/10.4000/miranda.8220

This text was automatically generated on 16 February 2021

\section{(c) (i) (9)}

Miranda is licensed under a Creative Commons Attribution-NonCommercial-NoDerivatives 4.0 International License. 


\section{Susan Glaspell Revisited: Century Old Play Returns to its Roots}

Performance Review

Denise Doherty Pappas

\section{Factual information about the show}

1 The Verge at the Provincetown Theater (MA, USA)-November, $11^{\text {th }}$ to November, $22^{\text {th }}$ 2015.

Author: Susan Glaspell

Directors: Nathan Butera and Frank Vasello

Cast: Linda Bradshaw, Paul E. Halley, Cynthia Harrington, Jody O'Neil, Tome Sharp, Bragan Thomas

Provincetown Theater website: http://provincetowntheater.org/

\section{Review}

Before the curtain rose at the Provincetown Theater on the brilliant production of The Verge, Director Frank Vasello addressed the audience. He told us this was the first full length expressionist feminist play, performed only ten times in a century, produced for the first time ever in Provincetown, MA, where it was written by Susan Glaspell in 1921. She created a post-suffrage era drama years before Virginia Woolf's introduced Mrs. Dalloway and "A Room of One's Own" to the world. At age 45, Glaspell was a seasoned wife, journalist, author and playwright examining the question "what is next for women's progress?". Her audience was composed of "new Women" and their friends who were schooled by Margaret Sanger's magazine "Women Rebel" whose motto proclaimed "no gods, no masters."

3 Glaspell explores this subject matter through the life of her character, Claire Archer, an ambitious botanist who seeks critical independence to achieve her life work. ${ }^{1}$ Claire is attempting to create a new plant called "Breath of Life". But at every turn she is 
interrupted by friends and family who demand Claire's time and attention. While everyone agrees with Claire's husband that "she had a fire within" her sister her daughter along with her two lovers (Tom and Dick) and her spouse (Harry) complain to Claire expecting her to follow their wishes, to meet their needs. Their suggestions: be more motherly, a better hostess, a more attentive lover, go shopping! Claire's response: "We need not be held in forms molded for us". Frustrated by their badgering, Claire retreats to a private tower.

4 Alone, Claire questions "what is there beyond the stars?". She desires more than a conventional life but acknowledges the steep price to be paid for her freedom. "It's lonely here on top" she acknowledges. When her latest flame Tom, bearing the ironic last name "Edgeworthy", begs her to run away with him saying "I can make you safe" Claire rejects his offer admitting "You are too much. You are not enough." Unlike Ibsen's Nora, an earlier generation's feminist identity seeker, Claire does not walk out. Instead, she views Tom as an obstacle to be destroyed. She strangles him so that she can carry on with her real passion, her godhead, her career project, i.e. "The Breath of Life". "I saved myself", Claire says before singing "Nearer my God to Thee.". As the curtain falls, the Jefferson Airplane wails "when the garden flowers/ Baby are dead/ Yes/And your mind, your mind/Is so full of red./Don't you want somebody to love?".

5 Actor Linda Bradshaw played the role of Claire with professional skill. She changed her character from determined botanist to conflicted lover to spontaneous murderer in a single scene, effectively using her expressive eyes and body language to display the rage and rawness of Claire's psyche. Likewise, Jody ONeil, as Claire's husband, Harry Archer, showed special comedic skills especially in the opening scene when his character (yearning for an egg with salt) came up empty handed through many attempts to have this breakfast despite his patriarchal blustering.

6 The Breath of Life plant was prominently placed at center stage; audience members couldn't miss the cast revolving around this symbolic plant for the entire play, wondering its fate. Ed Christie's special effects were illuminating. Claire's precious project lit up symbolizing her potential creative life. The entire cast put their hearts into this play's homecoming to Provincetown, Massachusetts where Susan Glaspell also returned in her later years.

7 The Verge stands the test of time. Director Frank Vasello shared directorial credit with Nathan Butera with their production company called "Seize the Roses," Post production, Frank told me only minor script changes were taken because the theme feels so contemporary. For example, they omitted Glaspell's use of "strumpet" because of its old fashioned connotation.

8 Yet thematically, to this day, breaking out beyond societal expectations remains a major challenge even in the most liberal countries. Wanting to love and be loved is a powerful driver but realizing one may loose or give up one's self in the process is an ongoing human dilemma. Men continue to seek intelligent partners but balk when those partners put their careers above their relationships. Is love liberating or enslaving? Do men exploit women? When are we too selfish? When are we too selfless? The Verge conjures up these pertinent questions.

9 A century later, journalist Susan Glaspell would feel right at home reading today's political headlines. Conservatives still yearn to control women's behaviors from womb to tomb. They trash Planned Parenthood and Hillary Clinton at every turn. Worldwide the struggle for individual freedom continues while women remain on "the verge". 
Classic plays such as this fine production remind us progressive generations struggled before us proving we are not alone.

[Photo 1]

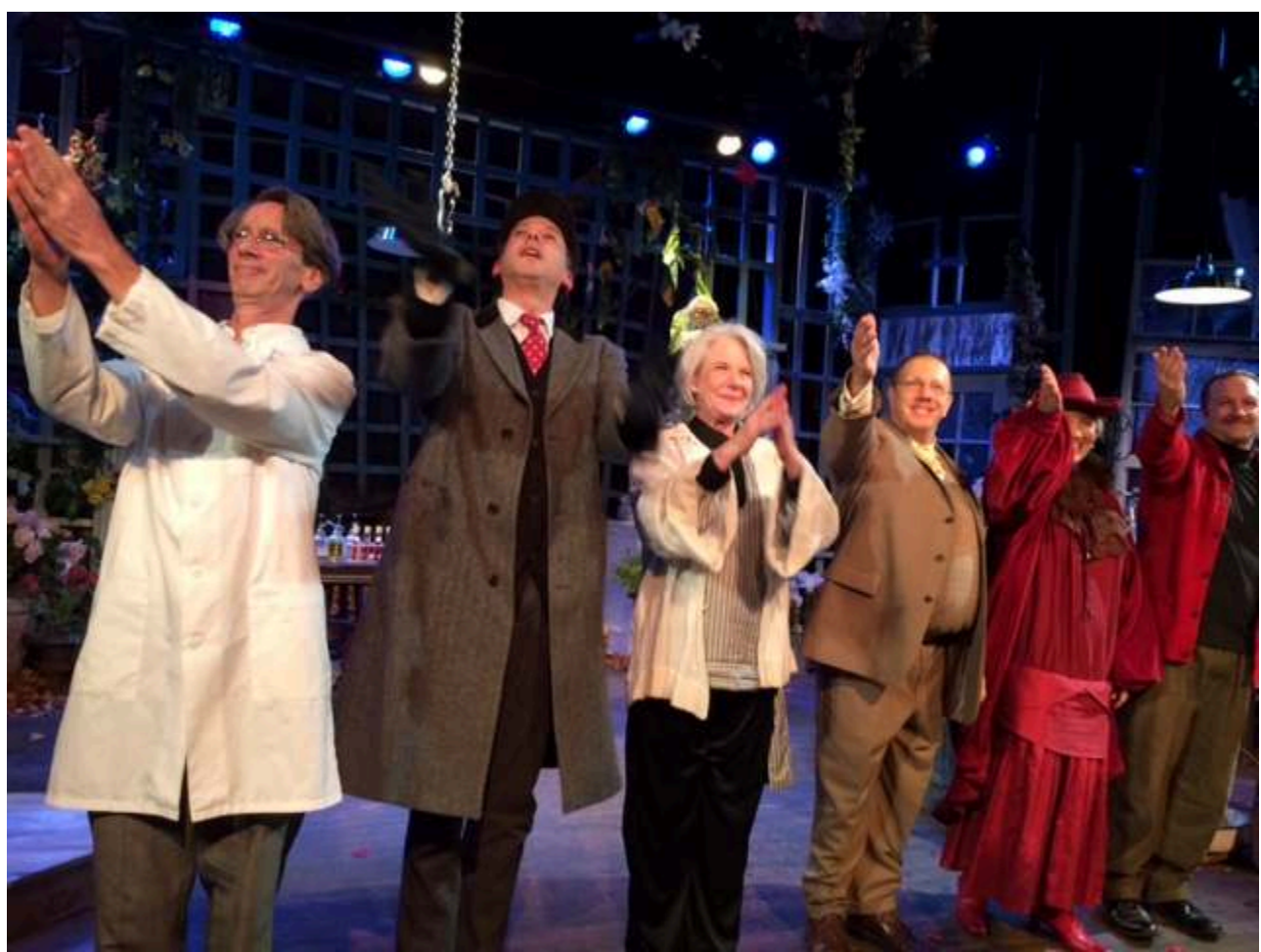

Paul E. Halley as Anthony and Dr Emmons, Bragan Thomas as Tom Edgeworthy, Linda Bradshaw as Clair Archer, Jody O'Neil as Harry Archer, Cindy Harrington as Elizabeth and Adelaide, Tome Sharp as Richard Demming.

Crédit photo : Nathan Butera

NOVEMBRE 2015, PROVINCETOWN THEATER (MA, USA)

\section{NOTES}

1. The Provincetown Theater lobby introduced and enhanced the story with a display of Claire Archer memorabilia including a photo of Claire with Madame Curie and Claire's scientific abstracts and botanical drawings. 


\section{ABSTRACTS}

Theatre review, November 2015

Show: The Verge at the Provincetown Theater (MA, USA)-November, $11^{\text {th }}$ to November, $22^{\text {th }} 2015$.

Critique théâtrale, Novembre 2015

Spectacle: The Verge au Provincetown Theater (MA., USA)-11 novembre au 22 novembre 2015

INDEX

Mots-clés: actualité, amour, critique de théâtre, émancipation, expérimentation, féminisme, modernisme, New Woman, science

Subjects: Theater

Keywords: contemporary, emancipation, experimentation, feminism, love, modernism, New Woman, science, theater review

\section{AUTHORS}

\section{DENISE DOHERTY PAPPAS}

Author of John Simmons; The Measure of A Man.

Provincetown, MA, USA 